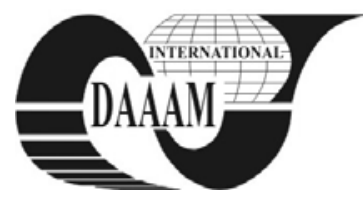

\title{
THE IMPORTANCE OF THE MANAGEMENT OF CONSULTING COMPANIES, CONCERNING THE COMMERCIAL SOCIETY DURING THE ECONOMICAL CRISIS
}

\author{
NECSULESCU, E[caterina]; POCORA, M[ihail] - S[ilviu]; NECSULESCU, M[arina] - D[iana]; MIRONOV \\ DURET, G[abriela] N[icoleta]; DURET, N[icu] \& ONCIOIU, I[onica]
}

\begin{abstract}
Foundation of a company is the first step in developing a business. Consulting firms have developed to rachieve the industrial objectives in order to provide management consultancy, audit, legal, technical. They have an important role in standardization of technical norms and regulations, commercial, financial, accounting and law in the business of national and international businesses. Through direct involvement in market transactions between corporations, these firms have made possible the development of mega-business mergers and acquisitions.
\end{abstract}

Key words: consulting, socio economic instability, blocking sphere

\section{INTRODUCTION}

The economic crisis seems to have had other beneficial effects on managers of consulting companies. They are more attentive to the way that explores the impact of projects.

All these changes have been catalyzed by the economic crisis that has managed to remove a large part of the management of the Romanian state of dreaming and self-sufficiency. The pressure on profitability, efficiency and attention to the customer will continue and transform the organizational environment of the consulting companies in a more structured and healthy.

In these circumstances management has only one option to ensure their survival: increasing levels of professionalism and assimilation of modern management tools and techniques of the company.

\section{CONSULTING COMPANIES FIGHT WITH ECONOMIC CRISIS}

Consulting services assist public and private organizations to analyze and redefine their strategies, to improve efficiency in operations and to optimize human resources and technology. Consulting is composed of:

\subsection{Business Consulting (BC) including:}

- Strategic Consulting, which aims to improve longterm business: strategic planning, mergers and acquisitions, sales, marketing, communication, financial, human resources strategy.

- Operations Management, which seeks to integrate business solutions through Business Process Reengineering (BPR), customer relationship management systems (CRM), (Olaru, 2008) restructuring / reduction of cost management, procurement and suppliers. Project Management Change management, consultancy services, related to other advisory services, assisting the organization to manage the impact that change has on human resource organization.

- Human Resource Consulting: Consulting services aimed at improving the item "human" of the organization by: measurement and performance management, organization of system benefits, compensation and retirement, human resources strategy and marketing, talent development, management coaching.

\subsection{Consultancy in Information technology}

It assists organizations to evaluate their IT strategy to align technology with business processes. These services include strategic planning and design, operation and implementation. Consultancy, regardless of its area of expertise, is the star of Western practitioners who have gained ground in Romania. Companies struggle with the economic crisis took most of the time as draft reorganization and growth performance.

The general impression is that management has become more interested to explore how to create added value in the company. Instead of perceiving (Buhociu \&. Negoescu, 1999) business processes as a black box that arises between resources and revenues, management tries to follow the logic: "I understand - measures - optimize / transforms - automates. Management is more realistic in terms of return on investment. Instead of expect a return on investment in the short term, most have reset expectations to 2-3 years, in the opinion of consultants approach is more realistic and healthy for the Romanian companies.

The market will take advantage of the need for companies to restructure its activities, to control costs and streamline operations. Even if the boom will not know the past years, services and advice will be sought during the recession, experts say, and the main players are optimistic estimates.

The contraction of the economy is clearly mirrored in corporate budgets. Companies had to reduce funding for several departments under pressure to shelve projects consumption decline and liquidity (Negoescu et al., 1998) problems in the market rigidity.

Money has become more expensive than in the first half of last year, and companies have come much more cautious and oriented to restructure the business. In these circumstances, what chances are for consulting firms to aspiring to miserly company's budgets? Professional players on the Romanian market and remain optimistic and consider crisis a very opportune period, even if the professional services sector felt the problems in the economy. But many companies have plans about business reorganization, reduction costs, and increase efficiency.

A diagnostic analysis is required when the unit is in difficulty, to identify the causes and measures to repair faults, but also when the unit operates, at least apparently normal.

Based on diagnostic analysis will aim to identify opportunities to improve performance, as well as future trends malfunctioning generators. It is considered that due diligence is essential when:

- actions are initiated by industrial restructuring / privatization / sale / purchase / transfer shares; 
- undertake joint ventures, joint ventures set up is initiated collaborations with foreign partners; a crisis is found in the unit;

- $\quad$ aims to improve preventive control;

- $\quad$ enter into management contracts renewed;

- $\quad$ apply for loans or subsidies to budget undertakings. The reasons why companies come to a point in the impasse is not always generated by the economic crisis.

They can be grouped into:

- Protective Management: autocracy, limited capabilities, the owner is the manager, there is a succession plan;

- Business strategy: rapid growth, several acquisitions, and unrelated diversification in new areas, dependence on a single customer or supplier;

- Liquidity: no maneuvering space, excessive use of short-term credit,

- Financial Profile: superficiality in control, high leverage

\section{INFORMATION BUSINESS CONSULTING - EUROPEAN PROJECTS}

Consulting firms continue to collect big money from the realization and implementation of European projects. For this, consulting firms in EU funds agriculture and rural development are often contacted to file the stages of financing and project implementation. Also, most consulting firms do not provide such financial instability as long as European funds will be allocated to Romania after 2013.

European projects that have brought large sums of money were the consulting firms of SAPARD, the European Regional Development Fund, and the Regional Operational Programme PHARE. Furthermore, significant amounts of European consulting firms depend upon the amount of eligible project selected for funding. In most cases, to simply consulting project, the beneficiary can pay three percent of the eligible project. But the percentage may increase to eight percent, according to the beneficiaries' construction contracting and design consultancy.

Trend consulting European funds covering several areas. Many contracts for projects are coming from tourism, agriculture and even the economic. They were especially attracted European funds for modernization of agricultural holdings, renovation of villages, creating micro-enterprises and even the establishment of boarding houses. In addition, representatives of EU funds consulting firms say the market is manifested Iasi fierce competition among consulting firms in European projects.

Proof of success does consulting firms and consultant's ability to achieve European projects. A good consultant should be in European funds have substantial knowledge in economics, finance, marketing, management and agriculture. In addition, the consultant must provide proof of European funds to the client of leadership skills and strategic planning. It is an activity that you require in terms of intellectual.

\section{BUSINESS CONSULTING AND ONLINE SUPPORT}

More and more small and medium-sized companies need specialized consulting experience in business. Local companies on the market in the field are generally concentrated only on the major players in the market, while small and medium business segment is virtually bare at the moment.

Small Businesses, launched in the current economic climate, also benefit from a major opportunity, which is on flexibility and adaptability to the environment, big companies respond to changes made harder by the crisis.
The services offered by consulting companies include testing the feasibility of business idea, preparing a business plan and financial projections, design a business model and identify the sustainable competitive advantages.

In general, starting a business in a recession brings major opportunities. Lower costs for start-up and operation, higher bargaining power against suppliers, availability of resources or the possibility of identifying new niches and competitive advantages (Ariton \& Negoescu, 1998) amid changes in market and competitive environment are redefining some of the "advantages" of the crisis. The main reason for a lot of small transactions fail is about a lack of adequate marketing in terms of attracting potential investors.

Development consultancy services on-line has a high potential for the business looking for ideas to identify solutions for implementation, Internet search software are increasingly replacing traditional touch. But the initial contact, the information comes via the Internet. According to experts, (Nicolescu \& Verboncu, 2008) the services provided by specialized websites grow continuously. From the simple presentation page offers advice reached by email and even on-line messaging systems, including video conferencing.

Multiplying these Internet sites, offering alternative services consulting, turnkey, business environment, represent an opportunity, both in terms of the variety of supply and service cost. Dozens of economic consulting firms have opened sites on the Internet and give advice including messenger and email.

And that given that obviously when you have financial problems to solve is the speed with which fundamental most clients of business consulting services came from the internet (72\%) and a 55\% learned through advertising opportunities online, visit the rest from searching, references, or direct visits.

\section{CONCLUSION}

According to representatives of companies that prevent the market is negative and invest in consulting, crisis period is considered the right time, as there are many companies that do not have sufficient funds for counseling services.

Knowledge of these effects is important for management companies on this basis that management decisions can be taken to counteract negative influences that can exploit these factors and their positive influences.

Firms focused on controlling. After a year, consultancy was regarded as a luxury or as an attribute of innovation and development-oriented companies. In this moment, these services become more of a deadlock solution for companies and incurred in a critical situation, in which survival of the company is the first point on the daily agenda of top management.

\section{REFERENCES}

Buhociu, G. Negoescu . (1999). Economic analysis. Braila: Eureka Publishing

Ariton, D. \& Negoescu, G.. (1998). Accounting and consulting techniques. Galat: Algorithm Publishing

Negoescu, G.; Buhociu, F.; Bontas, C.\& Obradovic, C. (1998). Creditworthiness operators. Galati : Algorithm Publishing

Nicolescu, O. \& Verboncu. I. (2008). Management. Bucuresti: Ed.Universitaria

Nicolescu, O.(2006). Management

comparat.București:Ed.Economică.

Olaru, A. ( 2008). Management. Galati, Ed. Europlus

Constantinescu A.(2002).Management

comparat.București,Ed.Natională 